\title{
Quantitative Determination of the Heavy Metal Levels in the Wild Edible Plant Parts and their Corresponding Soils of the Central and Western Regions of the Oromia State, Ethiopia
}

\author{
Adugna Boke ${ }^{1,2 *}$, Negussie Megersa ${ }^{2}$ and Endale Teju ${ }^{2}$
}

${ }^{1}$ Department of chemistry, Faculty of Natural Science, Samara University, P. O. Box 132, Samara, Ethiopia

${ }^{2}$ Department of Chemistry, College of Natural Sciences, Addis Ababa University, P. O. Box 1176, Addis Ababa, Ethiopia

\begin{abstract}
This study was designed to assess the levels of selected metals ( $\mathrm{Pb}, \mathrm{Cu}, \mathrm{Zn}, \mathrm{Cd}, \mathrm{Ni}, \mathrm{Cr}$ and $\mathrm{Ca}$ ) in wild edible plants and their corresponding soil samples by FAAS. A wet digestion procedure has been adopted to digest the plant and soil samples. The validity of the method was evaluated by spiking the sample with a standard of the selected metals. The levels of $\mathrm{Pb}, \mathrm{Cd}, \mathrm{Ni}, \mathrm{Cu}$ and $\mathrm{Cr}$ were below detection limits in all the edible parts of the studied plants except in the root of Eriosema cordifolium where $\mathrm{Ni}$ and $\mathrm{Cr}$ were detected. Similarly, only $\mathrm{Ni}$, $\mathrm{Cu}$ and $\mathrm{Cr}$ were detected in the soil samples of Eriosema cordifolium and Physalis peruviana plants. But, Zn, and Ca were detected in all the studied samples and varied in the range 31.3-157.5 and 24.4-6214.3 $\mathrm{mg} \mathrm{kg}^{-1}$ in plants and 55.4-149.8 and 367.1-6032.3 mg $\mathrm{kg}^{-1}$ in soil samples, respectively. However, the value of selected metals in soils and plants sample were lower than the permissible limit recommended by European Union Standard and Joint FAO/WHO Expert Committee on Food Additives respectively with the exception of $\mathrm{Zn}$ in tuber of Pachyeymbium sacculatium plant.
\end{abstract}

Keywords: Wild edible plant; FAAS; Heavy metals; Accumulation; Uptake

\section{Introduction}

Wild edible plants (WEPs) refer to plant species that are neither cultivated nor domesticated, but are available from their wild natural habitat and used as sources of food. They play important role in maintaining food supplement as a means of survival during times of drought and famine [1]. Their uses have been overlooked though their consumption is still very common in rural areas of some countries including Ethiopia [2]. In Ethiopia, their occurrence and availability is mainly determined by the seasonal variation and their abundance increases during the rainy seasons but decreases during dry seasons [3].

Ethiopia is known for endemism of wild plant species which are used in different ways, including as medicine and food. The flora compromises approximately 6000 species of higher plants of which about $10 \%$ are endemic $[4,5]$. As a result, the country is known as a "biodiversity hot spot" and center of origin and diversification for a significant number of food plants [6,7]. Ethno-botanical studies conducted in Ethiopia have indicated that over 300 species of wild plants are gathered and consumed by the people [8,9]. The rural people traditionally harvest wide range of leafy vegetables, roots, tubers and fruits from wild plants because of their taste, cultural uses and as food supplements [10]. Consumption of such plants by children and sometimes adults is, thus, an integral part of the different cultures in the country [11]. Among the wild edible plants; root of Eriosema cordifolium, root of Commiphora confusa Vollesen, tuber of Pachyeymbium sacculatium and fruit of Physalis peruviana were selected for the study. Especially the root of Eriosema cordifolium and fruit of Physalis peruviana are highly consumed by children.

Plants get nutrient from environmental compartment (soil, water and air). But they are not perfectly selective only to essential nutrients; they may take up metals like heavy metals that are toxic even at low level. Soil is considered a critical environment as it accumulates pollutants (like heavy metals) that can be dispersed in it, both naturally and by various anthropogenic activities [12]. The total metal content in soil is not a good indicator of exposure or risk to plants or organisms since only a portion of the metal present in soil is potentially available for the plants. The dissolved and exchangeable forms of metals are available to the plants while the metals available as structural components of the lattices of soil minerals and insoluble precipitates with other soil components are potentially available in the longer term [13].

Metals present in the soil fractions vary in degree of mobility. Their bioavailability is regulated by soil properties (physical, chemical and biological processes) and interactions between them [14]. Changes in the chemical properties of the soils greatly affect concentration of free metals and result in changes in their availability for plants. With increasing $\mathrm{pH}$, contents of organic matter and clay; solubility of most metals are decreased due to their increased tendencies for adsorption [12].

Plants readily assimilate elements through the roots. The direct contact between the plant root and soil allows most metals to enter the plant tissue through uptake of water and nutrients by plants, ion exchange at cell wall and other complicated metabolic mechanisms [15]. Once metals taken up by roots, they can either be stored by the roots or transported to other parts of the plant. So, plants take up metals and accumulate them in their edible and nonedible parts in quantities high enough to cause risks both to animals and human beings consuming these metal rich plants [16]. In particular, heavy metals pose a great health risks to all living organisms upon long term exposures [17-

*Corresponding author: Adugna Boke, Department of chemistry, Faculty of Natural Science, Samara University/ Addis Ababa University, PO. Box 132 Samara, Ethiopia, Tel: 251-1-0336660618; Fax: 251-1-0336660621; E-mail: adugnabo@gmail.com

Received April 29, 2015; Accepted June 01, 2015; Published June 05, 2015

Citation: Boke A, Megersa N, Teju E (2015) Quantitative Determination of the Heavy Metal Levels in the Wild Edible Plant Parts and their Corresponding Soils of the Central and Western Regions of the Oromia State, Ethiopia. J Environ Anal Toxicol 5: 299. doi:10.4172/2161-0525.1000299

Copyright: (c) 2015 Boke A, et al. This is an open-access article distributed under the terms of the Creative Commons Attribution License, which permits unrestricted use, distribution, and reproduction in any medium, provided the original author and source are credited. 
20]. Because of their non-biodegradability, long biological half-lives, potential to accumulate in different body parts and their solubility in water; the possibility of causing deleterious health effects is high [14]. Even at low concentration levels they have damaging effects to man and animals since there is no good mechanism for their elimination from the body [16]. They disrupt metabolic functions in two ways: the first is being accumulated in the body, they can disrupt functions in vital organs and glands such as the heart, brain, kidneys, bone, liver, etc. and secondly, they can displace the vital nutritional minerals from their original place, thereby, hindering their biological functions [14]. Because of this, they can pose serious risks to the consumers in terms of carcinogenesis, mutagenesis and teratogenesis and also lead a number of nervous, cardiovascular, renal, neurological impairment as well as bone diseases and several other health disorders by these two ways [21]. From the above, it is well understood that wild edible plants accumulate considerable quantities of essential and non-essential metal in their edible parts. As a result, these metals directly available to the consumers since the selected wild plants are consumed without undergo a process. Because of this, the consumers could suffer from metal toxicity and their normal body can be affected. Since such study are not get a serious attention in Ethiopia, it is very important to determine the level of the essential and toxic metals in the wild edible plants. Therefore, the proposed study will be focusing on the analysis of the concentrations levels of the accumulated heavy metals in the selected wild edible part of plants and in their corresponding soils. It is also hoped that findings of the study could be utilized as baseline information for the quality control.

\section{Materials and Methods}

\section{Chemicals and reagents}

All chemicals used in this study were of analytical grade reagents. Hydrochloric acid (36-38\%) and nitric acid (69-72\%) were obtained from Sigma Aldrich (Steinleim, Germany); perchloric acid (70\%) was received from the Research Lab. Fine Chem. Industries (Mombai, India) and potassium chloride (99\%) was purchased from Lamberk Chemicals pvt. Ltd (Ambala cantt, India) and the reference standards of the heavy metals under study were the products of Perkin Elmer (Boston, USA). The stock standard solutions, $1000 \mathrm{mg} \mathrm{L}^{-1}$, were prepared from the nitrate salts of the metals. The working standard solutions of the selected metals were prepared freshly from the intermediated standard solutions $\left(100 \mathrm{mg} \mathrm{L}^{-1}\right)$ which was obtained by diluting stock standard solutions.

\section{Instruments}

ZEEnit 700P model flame atomic absorption spectroscopy (Germany) equipped with deuterium ark background corrector, nebulizer, auto sampler and hollow cathode lamp was used for determination of the levels of selected metals. Other instruments including an oven (Germany) for drying of the samples; muffle furnace (Germany) for ashing of the soil samples in order to determine the organic content; ceramic mortar and pestle (USA) for grinding and homogenizing the samples; digital analytical balance, Adam Equipment (Jermany) for weighing samples; Kjeldahl (England) for digesting the samples; conductometer and $\mathrm{pH}$ meter (Romania) used for measuring electrical conductivity and $\mathrm{pH}$ of the soil samples were also utilized. All glassware used were first kept overnight in a $10 \% \mathrm{HNO}_{3}$ solution and then repeatedly washed with distilled-deionized water and dried in an oven for $24 \mathrm{~h}$ before use.

\section{Description of the study area}

The wild edible plants and their soil samples were collected from different localities of Oromia regional states, Ethiopia. Particularly from Jimma Rare and Yaya Gulale which are located in Horro Guduru Wellega and North Showa Zone of Oromia Regional state respectively. The geographical locations (latitude, longitude and elevation) of Sampling sites were $09^{\circ} 28^{\prime} 1.44^{\prime \prime} \mathrm{N}, 37^{\circ} 26^{\prime} 2.34^{\prime \prime} \mathrm{E}, 2293.50 \mathrm{~m}$ for Jimma Rare and $09^{\circ} 42^{\prime} 2.9^{\prime \prime} \mathrm{N}, 38^{\circ} 03^{\prime} 4.2^{\prime \prime} \mathrm{E}, 2760.00 \mathrm{~m}$ for Yaya Gulale . Their distance from Addis Ababa, i.e., capital city of Ethiopia is $245 \mathrm{~km}$ and $113 \mathrm{~km}$ respectively. Eriosema cordifolium, Physalis peruviana and their corresponding soil samples were collected from Jimma Rare while Commiphora confusa Vollesen, Pachyeymbium sacculatium, were collected from Yaya Gulale. Soil samples were collected from all the corresponding sites of the plant materials. The scientific name of these plants was authenticated by the National Herbarium, Department of Plant Biology and Diversity Management, Addis Ababa University. All the experiments were conducted in the Analytical Chemistry Research Laboratory of the Department of Chemistry, Addis Ababa University, Ethiopia.

\section{Sample collection and preparation}

Edible parts of the plants were collected manually; using vinyl gloves for protecting hands. The bruised portions were removed and the remaining samples packed in the polyethylene bags for transporting to the Analytical Laboratory. In the laboratory, collected plant samples were washed with tap water and then with double distilled water to eliminate adsorbed dust and particulate matters. The plant samples were then cut and chopped into small pieces using plastic knife in order to facilitate drying. The samples were then air-dried for five to six days and further dried in a hot air oven at $50-60^{\circ} \mathrm{C}$ for $24 \mathrm{~h}$, to remove moisture and maintain constant mass. The dried samples were ground into powder using acid washed commercial mortar and pestle and then sieved to $0.425 \mathrm{~mm}$ mesh size. The sieved samples were finally stored in the polyethylene bags and kept in desiccators until the time of digestion.

Similarly, the soil samples were collected from the base of uprooted plant by auger and properly labeled and packed in polyethylene bags. Each soil sample was air dried at ambient temperature for three days and then, ground into powder using acid washed commercial mortar and pestle and sieved to $0.425 \mathrm{~mm}$ mesh. The sieved soil samples were stored in the polyethylene bags and placed in desiccators until the time of digestion.

\section{Optimization of the digestion procedure}

Different digestion procedure for the plant and soil samples were carried out using $\mathrm{HNO}_{3}, \mathrm{HClO}_{4}$ and $\mathrm{HCl}$ acid mixtures by varying volume of the acid mixture, digestion time and digestion temperature [22]. Optimized procedures were selected based on the usage of lesser reagent volume, shorter digestion time and reasonable mild temperature for obtaining clear and colorless solutions of the resulting digests. Based on this, the optimized parameter for digestion procedure were: $4 \mathrm{~mL}$ of $1: 1$ of $\mathrm{HNO}_{3}$ and $\mathrm{HClO}_{4}$ at $270^{\circ} \mathrm{C}$ for $3 \mathrm{~h}$ for wild edible plant parts and $5 \mathrm{~mL}$ of $3: 1: 1$ of $\mathrm{HNO}_{3}, \mathrm{HCl}$ and $\mathrm{HClO}_{4}$ at 210 and $240^{\circ} \mathrm{C}$ for $2 \mathrm{~h}$ for the soil samples.

\section{Digestion of the plant parts and soil samples}

For each of the wild edible plant parts, $0.5 \mathrm{~g}$ of powdered and homogenized samples were weighed and transferred to $250 \mathrm{~mL}$ of round bottom flask. To this, $4 \mathrm{~mL}$ of $1: 1(\mathrm{v} / \mathrm{v})$ of $\mathrm{HNO}_{3}$ and $\mathrm{HClO}_{4}$ was added and digested at $270^{\circ} \mathrm{C}$ for $3 \mathrm{~h}$. The digested solutions were allowed to cool and $5 \mathrm{~mL}$ of distilled-deionized water were added to dissolve the precipitate formed on cooling and gently swirled and 
Citation: Boke A, Megersa N, Teju E (2015) Quantitative Determination of the Heavy Metal Levels in the Wild Edible Plant Parts and their Corresponding Soils of the Central and Western Regions of the Oromia State, Ethiopia. J Environ Anal Toxicol 5: 299. doi:10.4172/2161-0525.1000299

Page 3 of 8

filtered into a $50 \mathrm{~mL}$ volumetric flask through Wattman filter paper no. 42. The clear solution then diluted up to $50 \mathrm{~mL}$ with distilled-deionized water and analyzed by flame atomic absorption spectroscopy.

Digestion of the soil samples on the other hand was carried out as follows: $0.5 \mathrm{~g}$ of crushed, powdered, sieved and homogenized soil samples were weighed and transferred to a $250 \mathrm{~mL}$ round bottom flask. To this, $5 \mathrm{~mL}$ of 3:1:1 ratio of $\mathrm{HNO}_{3}, \mathrm{HCl}$ and $\mathrm{HClO}_{4}$ were added. The solutions were then digested at $210^{\circ} \mathrm{C}$ for the soil of Commiphora confusa Vollesen and Pachyeymbium sacculatium and at $240^{\circ} \mathrm{C}$ for the soil of Eriosema cordifolium and Physalis peruviana for $2 \mathrm{~h}$. Then, the digested solutions were left to cool and $5 \mathrm{~mL}$ distilled-deionized water were added and gently swirled and filtered through Whatman filter paper no. 42. The filtrates collected in a $50 \mathrm{~mL}$ volumetric flask was filled to the mark with distilled-deionized water and analyzed by flame atomic absorption spectroscopy.

\section{Performances of the analytical method}

The detection limit is the lowest concentration or weight of analyte that can be measured at a specific confidence level. Near the detection limit, the signal generated approaches that from a blank and can be determined experimentally by running several blank samples to establish the mean and standard deviation of the blank. Accordingly, eight replicate blank samples were digested that have been utilized for the wild edible plant and the soil samples. Each of the blank samples was assayed for their heavy metal contents. The mean and standard deviations of the blanks were calculated to determine the method detection limit (MDL). It was then calculated using the following relation $[22,23]$

$$
\mathrm{MDL}=\mathrm{X}_{\mathrm{Bl}}+3 \mathrm{SD}_{\mathrm{Bl}}
$$

Where $\mathrm{X}_{\mathrm{Bl}}$ is the mean concentration of the analyte in the digested blank solution and $\mathrm{SD}_{\mathrm{BI}}$ is the standard deviation of the replicate measurements of the analytes in the blank.

\section{Validation of the analytical procedure}

Recovery is one of the most commonly used techniques utilized for validation of the analytical results and evaluating how far the method is acceptable for its intended purpose. Because of the absence of certified reference material for the wild edible plants and their soil samples; validity of the digestion procedures were assured by spiking the samples with a standard solution of known concentration of the target analytes.

The spiked wild edible plant and their soil samples were digested in triplicate following the same procedure used for digestion of the plant parts and the soil samples. The resulting digest of the spiked samples were then analyzed for their respective metal contents using FAAS and percent recoveries were calculated both for the plant parts and the soil samples.

\section{Characterization of the soil samples}

The bioavailability of heavy metals in the plant parts depends on a number of physical and chemical factors in the soils. These include: $\mathrm{pH}$, organic matter content and electrical conductivity.

Soil $\mathrm{pH}$ was measured in a suspension $(1: 2.5, w / v)$ of the soil and distilled water. $5 \mathrm{~g}$ of air dried soil $(<0.425 \mathrm{~mm})$ was weighed and transferred to a $100 \mathrm{~mL}$ beaker to which $12.5 \mathrm{~mL}$ distilled water was added. Then, the mixture was stirred and the $\mathrm{pH}$ was measured after allowing the suspension to stand for $10 \mathrm{~min}$, at room temperature.
Electrical conductivity of the soil samples was measured in a suspension $(1: 2.5 \mathrm{w} / \mathrm{v})$ of the soil and distilled water. $10 \mathrm{~g}$ of air dried soil $(<0.425 \mathrm{~mm})$ was weighed and transferred to a $100 \mathrm{~mL}$ beaker to which and $25 \mathrm{~mL}$ distilled water was added. The mixture was stirred and allowed to stand for $15 \mathrm{~min}$ at room temperature and the electrical conductivity was measured.

Soil organic matter content was determined using the method of loss on ignition. $5 \mathrm{~g}$ of the soil sample of the plant parts, which dried in oven at $100^{\circ} \mathrm{C}$ for $15 \mathrm{~min}$, was accurately weighed in to a pre-weighed crucible. Then, the crucible, with soil, was placed in a muffle furnace and heated at $520^{\circ} \mathrm{C}$ for $3: 30 \mathrm{~h}$. The sample was then taken from the furnace and placed in desiccators to cool. Then, the sample was reweighed and the percentage organic matter content was calculated.

\section{Results and Discussion}

\section{Evaluation of the proposed method performance}

The data qualities obtained from FAAS for metal analyzes are highly affected by the calibration curve. The calibration curves were prepared from a standards of known concentration; covering the concentration range expected in the sample. Then, the curves were established at four concentration levels corresponding to $0.25,0.5,0.75$ and $1 \mathrm{ppm}$ for $\mathrm{Cd}$ and $\mathrm{Zn} ; 1,2,3$ and $4 \mathrm{ppm}$ for $\mathrm{Cr}, \mathrm{Pb}$ and $\mathrm{Ni}$; and $0.25,0.5,1$ and $2 \mathrm{ppm}$ for $\mathrm{Cu}$ and $\mathrm{Ca}$. All the working standard of metals solution used for calibration curve exhibited good linearity with squared regression coefficients $\left(\mathrm{r}^{2}\right)$ ranged from 0.99281 to 0.99998 . The value of MDL was shown in Tables 1 and 2. As observed, the values of the detection limit of the method obtained were compared with the instrument detection limit and found to have greater values in all case. It was also less than the lowest working standard solution but approach to the starting point of the linearity of the calibration curve. This confirms that the method was good and acceptable. The limit of detection of the wild edible plant was slightly less than the soil sample of the plant since different mixture of blank solution used.

\section{Experimental procedure validation}

The accuracy of the proposed digestion method was evaluated by determining the recoveries of the spiked analytes at various concentrations. The values were nearly quantitative and in the acceptable range for the wet digestion method as observed in Table 2. Similarly the precision was evaluated by applying the method to the spiked samples of the edible plants and soils. Each sample was prepared in triplicate under the same experimental condition and analyzed. Then, the results of precision expressed as relative standard deviations (\%RSD) and are shown in Table 3. As can be seen, more or less acceptable precision (\%RSD less than 10) was obtained.

\section{Physiochemical parameters}

Metal solubility tends to increase at lower $\mathrm{pH}$ and most of the mobility of metals is reduced with increasing soil $\mathrm{pH}$ because of the precipitation as insoluble hydroxides, carbonates and organic complexes [24]. Usually the intensity of root uptake of metal by plants decreases with increasing soil $\mathrm{pH}$. Low soil $\mathrm{pH}$ value determines the activity of many metal ions in the water contained in the pores of the soil, affecting their bioavailability [25].

The value (mean \pm standard deviation, $\mathrm{n}=3$ ) of $\mathrm{pH}$, electrically conductivity $\left(\mathrm{mSm}^{-1}\right)$ and organic matter $(\%)$ of the plant soil were: 5.86 $\pm 0.02,0.09 \pm 0.01$ and $20.89 \pm 0.39$ for the soil of Eriosema cordifolium, $7.84 \pm 0.04,0.23 \pm 0.01$ and $4.98 \pm 0.15$ for the soil of Pachyeymbium sacculatium, $7.79 \pm 0.03,0.30 \pm 0.01$ and $7.20 \pm 0.04$ for the soil of Commphora confusa Vollesen and $6.00 \pm 0.09,0.04 \pm 0.01$ and $16.66 \pm$ 
Citation: Boke A, Megersa N, Teju E (2015) Quantitative Determination of the Heavy Metal Levels in the Wild Edible Plant Parts and their Corresponding Soils of the Central and Western Regions of the Oromia State, Ethiopia. J Environ Anal Toxicol 5: 299. doi:10.4172/2161-0525.1000299

Page 4 of 8

\begin{tabular}{|c|c|c|c|c|c|c|c|}
\hline Soil of : & Cd & $\mathrm{Cr}$ & $\mathrm{Cu}$ & $\mathrm{Ni}$ & $\mathrm{Ca}$ & $\mathrm{Pb}$ & Zn \\
\hline Eriosema cordifolium & BDL & $\begin{array}{l}39.60 \pm 0.02 \\
R S D \%, 5.05\end{array}$ & $\begin{array}{l}1.50 \pm 0.001 \\
R S D \%, 6.67\end{array}$ & $\begin{array}{l}39.81 \pm 0.042 \\
\text { RSD } \%, 10.55\end{array}$ & $\begin{array}{l}367.10 \pm 0.36 \\
\text { RSD } \%, 9.81\end{array}$ & BDL & $\begin{array}{l}85.50 \pm 0.03 \\
R S D \%, 3.51\end{array}$ \\
\hline Pachyeymbium sacculatium & BDL & BDL & BDL & $\mathrm{BDL}$ & $\begin{array}{l}3614.70 \pm 3.10 \\
\text { RSD } \%, 8.58\end{array}$ & BDL & $\begin{array}{l}133.50 \pm 0.01 \\
\text { RSD } \%, 0.97\end{array}$ \\
\hline Commiphora confusa Vollesen & BDL & BDL & BDL & BDL & $\begin{array}{l}6032.30 \pm 0.09 \\
\text { RSD } \%, 0.15\end{array}$ & BDL & $\begin{array}{l}55.40 \pm 0.02 \\
R S D \%, 3.61\end{array}$ \\
\hline Physalis peruviana & BDL & $\begin{array}{l}34.19 \pm 0.01 \\
\text { RSD } \%, 2.92\end{array}$ & $\begin{array}{l}6.10 \pm 0.01 \\
\text { RSD } \%, 10.39\end{array}$ & $\begin{array}{l}42.12 \pm 0.04 \\
\text { RSD } \%, 9.49\end{array}$ & $\begin{array}{l}539.00 \pm 0.33 \\
\text { RSD } \%, 6.12\end{array}$ & BDL & $\begin{array}{l}149.80 \pm 0.11 \\
\text { RSD } \%, 7.34\end{array}$ \\
\hline MDL(ppm) & 0.231 & 0.795 & 0.207 & 0.806 & 0.205 & 0.881 & 0.206 \\
\hline IDL (ppm) & 0.012 & 0.05 & 0.035 & 0.07 & 0.025 & 0.30 & 0.012 \\
\hline
\end{tabular}

BDL - Below Detection Limit, RSD - Relative Standard Deviation, MDL - Method Detection Limit, IDL - Instrumental Detection Limit

Table 1: Concentration of heavy metals $\left(\mathrm{mg} \mathrm{kg}^{-1}\right)$, (mean $\left.\pm S D, n=3\right)$ in the respective soil of wild edible plants.

\begin{tabular}{|c|c|c|c|c|c|c|c|c|}
\hline Wild edible plants & $\mathrm{pH}$ & Cd & $\mathrm{Cr}$ & $\mathrm{Cu}$ & $\mathrm{Ni}$ & $\mathrm{Ca}$ & $\mathrm{Pb}$ & $\mathrm{Zn}$ \\
\hline Root of Eriosema cordifolium & $\begin{array}{l}6.06 \pm 0.15 \\
R S D \%, 2.48\end{array}$ & BDL & $\begin{array}{l}5.14 \pm 0.40 \\
\text { RSD } \%, 3.89\end{array}$ & BDL & $\begin{array}{l}23.87 \pm 0.02 \\
R S D \%, 8.38\end{array}$ & $\begin{array}{l}1288 \pm 0.27 \\
\text { RSD } \%, 2.1\end{array}$ & BDL & $\begin{array}{l}44.0 \pm 0.02 \\
R S D \%, 4.55\end{array}$ \\
\hline $\begin{array}{l}\text { Tuber of Pachyeymbium } \\
\text { sacculatium }\end{array}$ & $\begin{array}{l}5.45 \pm 0.23 \\
\text { RSD } \%, 4.22\end{array}$ & BDL & BDL & BDL & BDL & $\begin{array}{l}6214 \pm 0.21 \\
\text { RSD } \%, 0.34\end{array}$ & BDL & $\begin{array}{l}157.5 \pm 0.09 \\
\text { RSD } \%, 5.71\end{array}$ \\
\hline \multirow{2}{*}{$\begin{array}{l}\text { Root of Commiphora confusa } \\
\text { Vollesen }\end{array}$} & $6.52 \pm 0.51$ & BDL & BDL & BDL & BDL & $1447.0 \pm 0.8$ & BDL & $49.4 \pm 0.02$ \\
\hline & RSD\%, 7.82 & & & & & RSD\%, 5.53 & & RSD $\%, 4.05$ \\
\hline \multirow{2}{*}{ Fruit of Physalis peruviana } & $4.22 \pm 0.25$ & BDL & BDL & BDL & BDL & $24.4 \pm 0.02$ & BDL & $31.3 \pm 0.03$ \\
\hline & RSD\%, 5.92 & & & & & RSD $\%, 8.2$ & & RSD $\%, 9.58$ \\
\hline MDL (ppm) & & 0.229 & 0.703 & 0.198 & 0.796 & 0.195 & 0.877 & 0.194 \\
\hline IDL (ppm) & & 0.012 & 0.05 & 0.035 & 0.07 & 0.025 & 0.30 & 0.012 \\
\hline
\end{tabular}

Table 2: Concentration of heavy metals $\left(\mathrm{mgkg}^{-1}\right),($ mean $\pm S D, n=3)$ in wild edible plants.

\begin{tabular}{|c|c|c|c|c|c|c|c|c|}
\hline & & Cd & $\mathrm{Pb}$ & $\mathrm{Cr}$ & $\mathrm{Cu}$ & $\mathrm{Ni}$ & Zn & $\mathrm{Ca}$ \\
\hline Root of Eriosema cordifolium & $\begin{array}{l}\text { \%R } \\
\text { (\%RSD) }\end{array}$ & $\begin{array}{l}99.0 \\
(5.2)\end{array}$ & $\begin{array}{l}91.8 \\
(5.0)\end{array}$ & $\begin{array}{l}93.5 \\
(10.2)\end{array}$ & $\begin{array}{l}88.00 \\
(9.45)\end{array}$ & $\begin{array}{l}93.48 \\
(6.15)\end{array}$ & $\begin{array}{l}90.74 \\
(8.40)\end{array}$ & $\begin{array}{l}91.89 \\
(5.21)\end{array}$ \\
\hline Tuber of Pachyeymbium sacculatium & $\begin{array}{l}\text { \%R } \\
\text { (\%RSD) }\end{array}$ & $\begin{array}{l}101.0 \\
(6.3)\end{array}$ & $\begin{array}{l}92.0 \\
(6.3)\end{array}$ & $\begin{array}{l}89.5 \\
(7.4)\end{array}$ & $\begin{array}{l}95.50 \\
(7.35)\end{array}$ & $\begin{array}{l}95.50 \\
(5.30)\end{array}$ & $\begin{array}{l}92.31 \\
(7.40)\end{array}$ & $\begin{array}{l}100.00 \\
(8.42)\end{array}$ \\
\hline Root of Commiphora confusa Vollesen & $\begin{array}{l}\text { \%R } \\
\text { (\%RSD) }\end{array}$ & $\begin{array}{l}100.0 \\
(5.2)\end{array}$ & $\begin{array}{l}92.0 \\
(5.1)\end{array}$ & $\begin{array}{l}94.0 \\
(10.4)\end{array}$ & $\begin{array}{l}91.50 \\
(8.01)\end{array}$ & $\begin{array}{l}98.25 \\
(2.40)\end{array}$ & $\begin{array}{l}110.42 \\
(6.15)\end{array}$ & $\begin{array}{l}95.80 \\
(6.15)\end{array}$ \\
\hline Fruit of Physalis peruviana & $\begin{array}{l}\text { \%R } \\
\text { (\%RSD) }\end{array}$ & $\begin{array}{l}101.0 \\
(6.1)\end{array}$ & $\begin{array}{l}92.0 \\
(6.0)\end{array}$ & $\begin{array}{l}105.5 \\
(6.0)\end{array}$ & $\begin{array}{l}99.00 \\
(2.15)\end{array}$ & $\begin{array}{l}96.50 \\
(2.41)\end{array}$ & $\begin{array}{l}108.57 \\
(8.25)\end{array}$ & $\begin{array}{l}97.76 \\
(8.20)\end{array}$ \\
\hline Soil of Eriosema cordifolium & $\begin{array}{l}\text { \%R } \\
\text { (\%RSD) }\end{array}$ & $\begin{array}{l}101.0 \\
(2.1)\end{array}$ & $\begin{array}{l}91.0 \\
(3.3)\end{array}$ & $\begin{array}{l}99.2 \\
(10.5)\end{array}$ & $\begin{array}{l}89.08 \\
(2.15)\end{array}$ & $\begin{array}{l}95.00 \\
(6.15)\end{array}$ & $\begin{array}{l}87.50 \\
(10.05)\end{array}$ & $\begin{array}{l}102.15 \\
(2.50)\end{array}$ \\
\hline Soil of Pachyeymbium sacculatium & $\begin{array}{l}\text { \%R } \\
\text { (\%RSD) }\end{array}$ & $\begin{array}{l}103.0 \\
(5.1)\end{array}$ & $\begin{array}{l}90.8 \\
(5.5)\end{array}$ & $\begin{array}{l}97.3 \\
(10.12)\end{array}$ & $\begin{array}{l}97.50 \\
(2.15)\end{array}$ & $\begin{array}{l}99.50 \\
(6.15)\end{array}$ & $\begin{array}{l}106.67 \\
(9.45)\end{array}$ & $\begin{array}{l}102.38 \\
(6.30)\end{array}$ \\
\hline Soil of Commiphora confusa Vollesen & $\begin{array}{l}\text { \%R } \\
\text { (\%RSD) }\end{array}$ & $\begin{array}{l}101.0 \\
(6.21)\end{array}$ & $\begin{array}{l}91.25 \\
(6.15)\end{array}$ & $\begin{array}{l}108.50 \\
(7.10)\end{array}$ & $\begin{array}{l}97.00 \\
(1.62)\end{array}$ & $\begin{array}{l}100.75 \\
(10.05)\end{array}$ & $\begin{array}{l}106.25 \\
(8.63)\end{array}$ & $\begin{array}{l}93.75 \\
(8.40)\end{array}$ \\
\hline Soil of Physalis peruviana & $\begin{array}{l}\text { \%R } \\
\text { (\%RSD) }\end{array}$ & $\begin{array}{l}100.0 \\
(6.02)\end{array}$ & $\begin{array}{l}91.0 \\
(6.25)\end{array}$ & \begin{tabular}{|l}
97.37 \\
$(10.07)$
\end{tabular} & $\begin{array}{l}92.39 \\
(6.15)\end{array}$ & $\begin{array}{l}92.86 \\
(10.02)\end{array}$ & $\begin{array}{l}109.09 \\
(10.10)\end{array}$ & $\begin{array}{l}93.33 \\
(8.42)\end{array}$ \\
\hline
\end{tabular}

Table 3: Recovery values (\%RSD, $n=3$ ) of the proposed method for plant and soil sample.

0.54 for the soil of Physalis peruviana respectively. The soil of Eriosema cordifolium and Physalis peruviana were slightly acidic where as that of Pachyeymbium sacculatium and Commphora confusa Vollesen slightly basic. Hence, metals are more mobile in the soil of Eriosema cordifolium and Physalis peruviana than soil of Pachyeymbium sacculatium and Commphora confusa Vollesen plant species.

The effect of $\mathrm{pH}$ on the mobility of metallic elements in the soil is highly variable, depending on the content of organic matter. The higher the soil organic matter content, the higher the ability of that soil to retain metals within it. So based on the result, the metals become more retained in the soil of Eriosema cordifolium and Physalis peruviana when compared with the soil of Pachyeymbium sacculatium and Commphora confusa Vollesen plant species. Therefore, the bioavailability of metals in soil for the plant species becomes low when the organic content of the soil is high due to the adsorption reaction of metals on it.

\section{Level of heavy metals in the soil of wild edible plants}

Heavy metals may enter the human body through inhalation of dust, direct ingestion of soil and consumption of food plants grown on metal contaminated of soil [26].

The most important pathway through which human exposed to the toxic metals are soil-plant-human (food chain) and soil-human (incidental soil ingestion). Out of the two soil-to-plants transfer is the key components of human exposure to metals. Therefore, analyses of the level of metals in soil are important.

In this study the concentration of heavy metals in the respective soil of WEP vary from one to other. The concentration of $\mathrm{Cd}$ and $\mathrm{Pb}$ in all soil samples become below detection limit where as the concentration of $\mathrm{Cr}, \mathrm{Cu}$ and $\mathrm{Ni}$ also below detection limit in the soil of Pachyeymbium sacculatium and Commiphora confusa Vollesen but detected in other 
Citation: Boke A, Megersa N, Teju E (2015) Quantitative Determination of the Heavy Metal Levels in the Wild Edible Plant Parts and their Corresponding Soils of the Central and Western Regions of the Oromia State, Ethiopia. J Environ Anal Toxicol 5: 299. doi:10.4172/2161-0525.1000299

Page 5 of 8

two soils of plants. Because the organic contents in the soil of Eriosema cordifolium and Physalis peruviana were high as compared with others. Hence, metals become more retained in the soil.

Metals like $\mathrm{Cr}, \mathrm{Cu}, \mathrm{Ni}, \mathrm{Zn}$ and $\mathrm{Ca}$ were detected in both soil sample of Eriosema cordifolium and Physalis peruviana plants because both soil samples were collected from the same area and their physiochemical parameters more or less the same. Likewise, only $\mathrm{Zn}$ and $\mathrm{Ca}$ metals detected in soil of Pachyeymbium sacculatium and Commiphora confusa Vollesen. This confirms that the physiochemical parameters of the soil affect the availability of metals in the soil samples.

The concentration of $\mathrm{Ca}$ in the soil of Pachyeymbium sacculatium (3613.7 $\mathrm{mg} \mathrm{kg}^{-1}$ ) and Commiphora confusa Vollesen (6032.3 $\mathrm{mg} \mathrm{kg}^{-1}$ ) were high as compared with other. The reason is higher $\mathrm{pH}$ values of the soil which can result in greater retention of metals, lower solubility of metals and also resulting in decreased leaching effects of the soils metals.

\section{Levels of heavy metals in wild edible plants}

Even though, the poor bioavailability of heavy metals in soil, the plants may have high ability to accumulate them in their different parts [27]. So, analyses of wild edible plants were important to identify and measure the level of metals. Metal concentrations in wild edible plants were different among species. Metals like $\mathrm{Zn}$ and $\mathrm{Ca}$ were accumulate in all wild edible plants studied. The root of Eriosema cordifolium plant was potentially accumulates $\mathrm{Ca}\left(1287.6 \mathrm{mg} \mathrm{kg}^{-1}\right)$ which greater than its respective soils. Similarly, the tuber of Pachyeymbium sacculatium plant was accumulate both $\mathrm{Ca}\left(6214.3 \mathrm{mg} \mathrm{kg}^{-1}\right)$ and $\mathrm{Zn}\left(157.5 \mathrm{mg} 7 \mathrm{~kg}^{-1}\right)$ that greater than its respective soils.

The root of Eriosema cordifolium and fruit of Physalis peruviana cannot accumulate $\mathrm{Cu}$ even if this metal available in their respective soils. Additional the fruit of Physalis peruviana plant species cannot accumulate $\mathrm{Cr}$ and $\mathrm{Ni}$ metals but the root of Eriosema cordifolium plant species accumulate. This may be because of the level of the metals in the plant which is not detected by FAAS, the bioavailability of these metals in soil, metal uptake ability of plants species and since plants absorb metals selectively.

\section{Correlation coefficient of metals}

A linear regression correlation test was performed to investigate correlations between metal concentrations in the wild edible plant and their respective soil samples. There is a perfect positive correlation when $r=+1$, no correlation when $r=0$, and a perfect negative correlation when $r=-1$. Hence, the closer the $r$ values to 1 or -1 , the stronger the relationship between the two variables.

There is a good correlation between the concentration of $\mathrm{Ca}$ and $\mathrm{Zn}(\mathrm{r}=0.9942)$ in the fruit of Physalis peruviana, $\mathrm{Cr}$ and $\mathrm{Ni}(\mathrm{r}=0.9907)$, $\mathrm{Cr}$ and $\mathrm{Ca}(\mathrm{r}=0.9083), \mathrm{Ca}$ and $\mathrm{Ni}(\mathrm{r}=0.8430)$ in the root of Eriosema cordifolium, $\mathrm{Cu}$ and $\mathrm{Ni}(\mathrm{r}=0.9992), \mathrm{Cu}$ and $\mathrm{Ca}(\mathrm{r}=0.8561), \mathrm{Ni}$ and $\mathrm{Ca}$ ( $\mathrm{r}=0.8761), \mathrm{Ni}$ and $\mathrm{Zn}(\mathrm{r}=-0.9919), \mathrm{Ca}$ and $\mathrm{Zn}(\mathrm{r}=-0.8077), \mathrm{Cu}$ and $\mathrm{Zn}$ $(\mathrm{r}=-0.9962)$ in the soil of Eriosema cordifolium, $\mathrm{Cr}$ and $\mathrm{Cu}(\mathrm{r}=0.9661)$ in the soil of Physalis peruviana, $\mathrm{Ca}$ and $\mathrm{Zn}(\mathrm{r}=0.9611)$ in the soil of Commiphora confuse Vollesen. But, it is not significant between Ca and $\mathrm{Zn}(\mathrm{r}=0.1233), \mathrm{Zn}$ and $\mathrm{Ni}(\mathrm{r}=-0.4299), \mathrm{Zn}$ and $\mathrm{Cr}(\mathrm{r}=0.3516)$ in the root of Eriosema cordifolium, Ca and $\mathrm{Zn}(\mathrm{r}=-0.6952)$ in the tuber of Pachyeymbium sacculatium, $\mathrm{Ca}$ and $\mathrm{Zn}(\mathrm{r}=0.5263)$ in the root Commiphora confuse Vollesen, $\mathrm{Cr}$ and $\mathrm{Cu}(\mathrm{r}=-0.5499), \mathrm{Cr}$ and $\mathrm{Ni}(\mathrm{r}=-$ 0.5162), $\mathrm{Cr}$ and $\mathrm{Ca}(\mathrm{r}=-0.0393), \mathrm{Cr}$ and $\mathrm{Zn}(\mathrm{r}=0.6209)$ in the Soil of Eriosema cordifolium, $\mathrm{Cr}$ and $\mathrm{Ni}(\mathrm{r}=0.6858), \mathrm{Cr}$ and $\mathrm{Ca}(\mathrm{r}=0.3345), \mathrm{Cr}$ and $\mathrm{Zn}(\mathrm{r}=-0.3962), \mathrm{Cu}$ and $\mathrm{Ni}(\mathrm{r}=0.4745), \mathrm{Cu}$ and $\mathrm{Ca}(\mathrm{r}=0.5666), \mathrm{Cu}$ and $\mathrm{Zn}(\mathrm{r}=-0.1456), \mathrm{Ni}$ and $\mathrm{Ca}(\mathrm{r}=-0.4565), \mathrm{Ni}$ and $\mathrm{Zn}(\mathrm{r}=-0.7896)$, $\mathrm{Ca}$ and $\mathrm{Zn}(\mathrm{r}=0.7328)$ in the soil of Physalis peruviana, $\mathrm{Ca}$ and $\mathrm{Zn}$ $(\mathrm{r}=0.7436)$ in the soil of Pachyeymbium sacculatium.

Even if the concentration of metals is high in the soil of plants: it may be low or high in the wild edible plants and vice versa. Hence, analysis was made to test whether or not significant relation exists between the metals concentration in the soil sample of plants and that taken up by wild edible part of plants. The result indicates, there are good correlations of $\mathrm{Zn}$ level between: soil and root of Eriosema cordifolium ( $\mathrm{r}=0.9999)$, soil and tuber of Pachyeymbium sacculatium $(\mathrm{r}=0.9487)$, soil and root of Commiphora confusa Vollesen $(\mathrm{r}=0.9989)$, soil and fruit of Physalis peruviana $(\mathrm{r}=0.9516)$. But the correlation of Ca concentration between soil and root of Eriosema cordifolium ( $\mathrm{r}=-$ 0.6747), soil and root of Commiphora confusa Vollesen ( $\mathrm{r}=0.3156)$, soil and fruit of Physalis peruviana $(\mathrm{r}=0.4776)$ were not significant as such $\mathrm{Zn}$ except that of soil and tuber of Pachyeymbium sacculatium ( $\mathrm{r}=-$ 0.9244). The correlation of $\mathrm{Cr}$ concentration between soil and root of Eriosema cordifolium was also good $(\mathrm{r}=0.9907)$ but for that of $\mathrm{Ni}$ it is not significant $(\mathrm{r}=0.3246)$.

\section{Trend of metals concentration in wep and their soil sample}

Plants and their soil sample do not accumulate metals equally. The accumulation and distribution were depending up on the environmental factor [28]. The level of $\mathrm{Cu}$ and $\mathrm{Ni}$ were high in the soil of Physalis peruviana but low in the soil of Eriosema cordifolium plant where as the level of $\mathrm{Cr}$ was high in soil of Eriosema cordifolium but low in soil of Physalis peruviana plant. The level of Ca was highest in the soil samples of Commiphora confusa Vollesen but lowest in the soil sample of Eriosema cordifolium. Accordingly, the level of $\mathrm{Zn}$ was highest in the soil sample of Physalis peruviana but lowest in the soil sample Commiphora confusa Vollesen.

The tuber of Pachyeymbium sacculatium plant species had highest concentration of $\mathrm{Ca}$ and $\mathrm{Zn}$ metals, but the concentration of these two metals were lowest in the fruit of Physalis peruviana plant as compared with the rest. This may be the capability of plant species to uptake metals. Once metals taken up by roots, they can either be stored in the roots or exported to the other part of plants. Efficient transport of metals to other part of plants is an important aspect of plant metal accumulation. The transport of metals from root to other part of plants is come out primarily through xylem. Organic acids and amino acids have frequently been reported to be the potential metal chelators, which most likely facilitate metal translocation through xylem. Without being chelated by ligands, movement of metal cations from roots to shoot (other part of plants) is expected to be severely retarded as xylem cell walls have a high cation exchange capability [29]. This may be a reason for a smallest accumulation of metals in the fruit of Physalis peruviana plant species (Figure 1).

The relationship between the levels of selected metals in the wild edible plants and their respective soil was varied. Some of the selected wild edible plant species showed higher concentration of metals even if the level of metals low in the soil. The level of $\mathrm{Zn}$ and $\mathrm{Ca}$ was higher in the tuber of Pachyeymbium sacculatium than its respective soil. Similarly, the concentration Ca was also higher in the root of Eriosema cordifolium than its respective soil.

As observed from Figure 2, plant species differ widely in their ability to accumulate the metals. Ca metal highly accumulated in the root of Eriosema cordifolium plant where as the fruit of Physalis peruviana plant accumulate the lowest $\mathrm{Ca}$ and $\mathrm{Zn}$ metals as compared with the other plant species. 

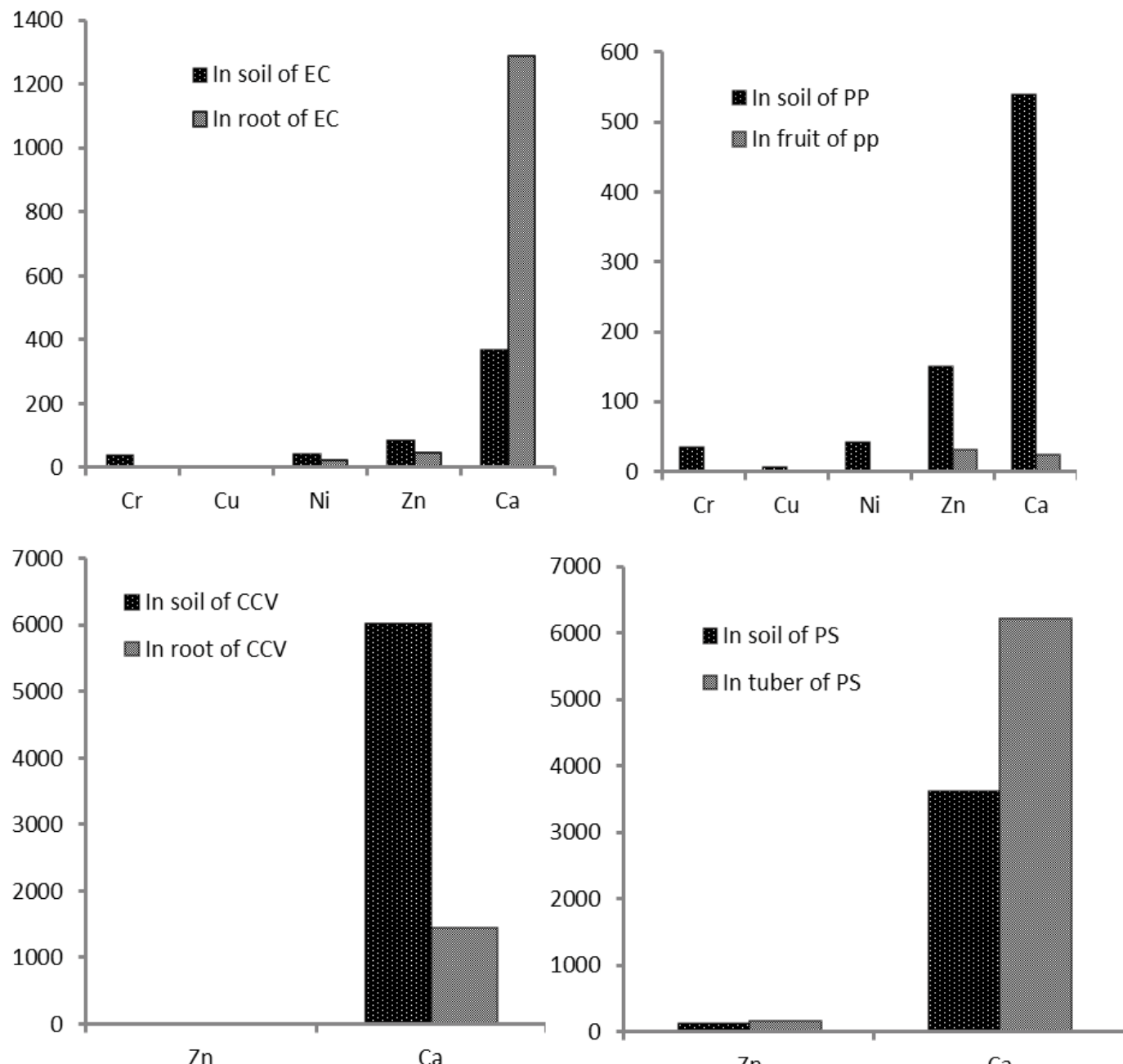

Where EC is Eriosema cordifolium; PP is Physalis peruviana; CCV is Commiphora confusa Vollesen and PS is Pachyeymbium sacculatium

Figure 1: Comparison of metals concentration between the WEP and their respective soil sample.

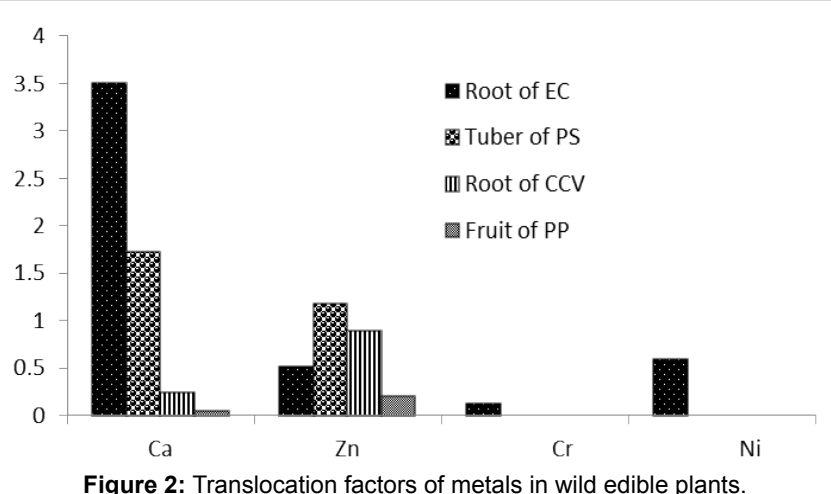

Comparison of metals level in soil sample with different standards

The European Union standards guide line for metals in soil were $100 \mathrm{mg} \mathrm{kg}^{-1}$ for $\mathrm{Cr}, 50 \mathrm{mg} \mathrm{kg}^{-1}$ for $\mathrm{Ni}, 100 \mathrm{mg} \mathrm{kg}^{-1}$ for $\mathrm{Cu}$ and $\mathrm{Pb}, 3 \mathrm{mg}$ $\mathrm{kg}^{-1}$ for $\mathrm{Cd}$ and $300 \mathrm{mg} \mathrm{kg}^{-1}$ for $\mathrm{Zn}(\mathrm{EU}, 2006)$. From this study, the soil concentration of metals was found in the range of: $39.81-42.12 \mathrm{mg} \mathrm{kg}^{-1}$ for $\mathrm{Ni}, 34.19-39.6 \mathrm{mg} \mathrm{kg}^{-1}$ for $\mathrm{Cr}, 1.5-6.1 \mathrm{mg} \mathrm{kg}^{-1}$ for $\mathrm{Cu}, 55.4-149.8 \mathrm{mg}$ $\mathrm{kg}^{-1}$ for $\mathrm{Zn}$ and 367.1-6032.3 $\mathrm{mg} \mathrm{kg}^{-1}$ for Ca but the level of $\mathrm{Pb}$ and $\mathrm{Cd}$ in the soil of plants were below detection limit of the FAAS. So, the analysis of metals in the soil sample of the plants shows that all the concentration of selected metals were lower than the permissible limit recommended by European Union Standards (EU, 2006).

\section{Comparison of metals level in wild edible plant with different standards}

The permissible limit recommended by FAO/WHO (2001) [30] were $73 \mathrm{mg} \mathrm{kg}^{-1}$ for $\mathrm{Cu}, 2.3 \mathrm{mg} \mathrm{kg}^{-1}$ for $\mathrm{Cr}, 67 \mathrm{mg} \mathrm{kg}^{-1}$ for $\mathrm{Ni}, 0.1 \mathrm{mg}$ $\mathrm{kg}^{-1}$ for $\mathrm{Cd}, 0.3 \mathrm{mg} \mathrm{kg}^{-1}$ for $\mathrm{Pb}$ and $100 \mathrm{mg} \mathrm{kg}^{-1}$ for $\mathrm{Zn}$ in the edible plants. The level of $\mathrm{Ni}$ and $\mathrm{Cr}$ in the root of Eriosema cordifolium was 23.87 and $5.14 \mathrm{mg} \mathrm{kg}^{-1}$ respectively which lower than the permissible limit. The concentration of $\mathrm{Zn}$ in all wild edible plant were lower than the permissible limit except in the tuber of Pachyeymbium sacculatium plant species (157.5 mg kg-1) which is above the FAO/WHO standard level. Similar the levels of metals like $\mathrm{Cd}, \mathrm{Pb}$, and $\mathrm{Cu}$ in all selected wild edible plant were found to be below the analytical method detection 
Citation: Boke A, Megersa N, Teju E (2015) Quantitative Determination of the Heavy Metal Levels in the Wild Edible Plant Parts and their Corresponding Soils of the Central and Western Regions of the Oromia State, Ethiopia. J Environ Anal Toxicol 5: 299. doi:10.4172/2161-0525.1000299

limit, indicating that the selected wild edible plants pose no health risk from these heavy metals: $\mathrm{Cd}, \mathrm{Pb}$, and $\mathrm{Cu}$.

\section{Translocation factor of metals from soil to plant}

The soil to plant transfer factor is one of the important parameters used to estimate the possible accumulation of metals. One approach to assess the bioavailability of metal to plants is to calculate the translocation factor of the plant. The translocation factor (TF) or mobilization ratio [31] is defined as follows:

$$
\mathrm{TF}=\frac{\text { Concentration of metals in plants parts }}{\text { Concentration of metals in the corresponding soil }}
$$

The TF values quantify the relative differences in bioavailability of metals to plants and identify the efficiency of a plant species to accumulate a given metal [32] and it determines relative translocation of metals from soil to other parts (root and shoot) of the plant species [31].

The TF value of Ca for Eriosema cordifolium and Pachyeymbium sacculatium were 3.51 and 1.72 respective. The TF value of $\mathrm{Zn}$ for Pachyeymbium aacculatium was 1.18. This indicates that Pachyeymbium sacculatium species is a $\mathrm{Ca}$ and $\mathrm{Zn}$ metal accumulator, but Eriosema cordifolium. Rich species is the most accumulator of Ca metal. The rest wild edible plant species is not as such to accumulate these two metals.

\section{Statistical analysis of the results}

Pair wise statistical analyses of the results were made to verify whether there was a significant difference in the metal contents between the wild edible plants and their corresponding soil. For the study, the significance of variation has been studied using one-way ANOVA and calculations were made using microcal (TM) origin ${ }^{\circ}$ version 6; copyright $\odot$ 1991-1999 microcal software.inc.

There was a significant difference $(p<0.05)$ at $95 \%$ confidence level for $\mathrm{Zn}$ and $\mathrm{Ca}$ contents between all the wild edible plants and their soil samples. Accordingly, significant different $(\mathrm{p}<0.05)$ at $95 \%$ confidence level for Ni content between the roots of Eriosema cordifolium and its soil samples were seen when pair wise comparison was made. However, insignificant variation ( $\mathrm{p}>0.05)$ at $95 \%$ confidence level for $\mathrm{Cr}$ content between roots of Eriosema cordifolium and its soil was observed. Significant difference in metals concentration between the wild edible plants and their soil samples may be the level and bioavailability of metals in the soil and the accumulation ability of plants [33].

\section{Conclusions}

Analysis of the level of metals in soil and plant were important since human exposed to the soil contaminant through: soil-planthuman (food chain) and soil-human (incidental soil ingestion). The level of $\mathrm{Cd}$ and $\mathrm{Pb}$ in soil sample of the plants was below detection limits where as that of $\mathrm{Cr}, \mathrm{Cu}, \mathrm{Ni}$ and $\mathrm{Zn}$ lower than the permissible limit recommended by European Union Standard. Hence, the soil of wild edible plants is not contaminated with the selected metals and safer for the plants growth and animals.

On the basis of metal contents in the wild edible plant and corresponding soil, it may be concluded that all the selected wild edible plant containing metals had lower than recommended tolerable levels proposed by Joint FAO/WHO Expert Committee on Food Additives, with the exception of $\mathrm{Zn}$ which exhibited elevated uptake in tuber of Pachyeymbium sacculatium plant species. Therefore, the tuber of Pachyeymbium sacculatium plant may not safe from the hazardous effects of $\mathrm{Zn}$. Generally, it is concluded that total concentrations and bioavailability of metals in soils as well as the ability of metal uptake are the main controls on their contents in plants.

\section{Acknowledgments}

The authors would like to express their heartfelt gratitude to the Department of Chemistry of the Addis Ababa University for the generous provision of the required laboratory facilities during the study period. Financial support received from the International Science Program (ISP) through ETH: 04 projects are greatly appreciated. Adugna Boke would like to thank Samara University, Ethiopia, for sponsoring his graduate studies.

\section{References}

1. Lulekal E, Asfaw Z, Kelbessa E, Damme P (2011) Wild edible plants in Ethiopia A review on their potential to combat food insecurity. Africa focus 24: 71-121.

2. Getachew A, Kelbessa U, Dawit D (2005) Ethno botanical study of edible wild plants in some selected districts of Ethiopia. Hum Ecol 33: 83-117.

3. Guinand Y, Dechassa L (2001) A Practical Field Guide to Wild Food Plants in Ethiopia: General Description; Edible Parts, Preparation Methods and Palatability. Addis Ababa, Ethiopia: UNDP-Emergency Unit for Ethiopia 110.

4. Friis I, Rasmussen F, Vollesen K (1982) Studies in the flora and vegetation of South West Ethiopia. Opera Botanica 63: 1-70.

5. Hedberg I, Friis I, Persson E (2009) In Flora of Ethiopia and Eritrea. The National Herbarium, Addis Ababa, Ethiopia and Uppsala, Sweden 8: 1- 7.

6. Harlan JR (1969) Ethiopia: a centre of diversity. Econ Bot 23: 309-314.

7. Edwards SB (1991) Crops with wild relatives found in Ethiopia. In: Plant Genetic resources of Ethiopia. Engles J, Hawkes J, Worede M (eds) Cambridge University Press, Cambridge 6: 42-47.

8. Asfaw Z, Tadesse M (2001) Prospects for sustainable use and development of wild food plants in Ethiopia. Econ Bot 55: 47-62.

9. Getahun A (1974) The role of wild plants in the native diet in Ethiopia. Agroecosystems 1: 45-56.

10. Mahapatra A, Mishra S, Basak U, Panda P (2012) Nutrient analysis of some selected wild edible fruits of deciduous forests of India: An explorative study towards non-conventional bio-nutrition. Advanced Journal of Food Science and Technology 4: 15-21.

11. Teklehaymanot T, Giday M (2010) Ethnobotanical study of wild edible plants of Kara and Kwego semi-pastoralist people in Lower Omo River Valley, Debub Omo Zone, SNNPR, Ethiopia. J Ethnobiol Ethnomed 6: 23.

12. Takac P, Szabova T, Kozakova L, Benkova M (2009) Heavy metals and thei bioavailability from soils in the long-term polluted Central Spis Region of SR. Plant Soil Environ 55: 167-172.

13. Aydinalp C, Marinova S (2003) Distribution and forms of heavy metals in some agricultural soils. Polish Journal of Environmental Studies 12: 629-633.

14. Nouri J, Khorasani N, Lorestan B, Karami M, Hassani AH, et al. (2009) Accumulation of heavy metals in soil and uptake by plant species with phytoremediation potential. Environ Earth Sci 59: 315-323.

15. Smical A, Hotea V, Oros V, Juhasz J, Pop E (2008) Studies on transfer and bioaccumulation of heavy metals from soil into lettuce. Environmental Engineering and Management 7: 609-615.

16. Arora M, Kiran B, Rani S, Rani A, Kaur B, et al. (2008) Heavy metal accumulation in vegetables irrigated with water from different sources. Food Chemistry 111 811-815.

17. Itanna F (2002) Metals in leafy vegetables grown in Addis Ababa and toxicological implications. Ethiop.J.Health Dev 16: 295-302.

18. Lasisi A, Ejelonu B, Nwosu F, Olayiwola M, Yusuf A (2006) Heavy metals and macronutrients contents in selected herbal plants of South-Western Nigeria. International Jour Chern 4: 71-76.

19. Obi E, Akunyili DN, Ekpo B, Orisakwe OE (2006) Heavy metal hazards of Nigerian herbal remedies. Sci Total Environ 369: 35-41.

20. Arpadjan S, Celik G, Taşkesen S, Güçer S. (2008) Arsenic, cadmium and lead in medicinal herbs and their fractionation. Food Chem Toxicol 46: 2871-2875.

21. Lokeshappa B, Shivpuri K, Tripathi V, Dikshit AK (2012) Assessment of toxic metals in agricultural produce. Food and Public Health 2: 24-29. 
Citation: Boke A, Megersa N, Teju E (2015) Quantitative Determination of the Heavy Metal Levels in the Wild Edible Plant Parts and their Corresponding Soils of the Central and Western Regions of the Oromia State, Ethiopia. J Environ Anal Toxicol 5: 299. doi:10.4172/2161-0525.1000299

22. Amde M, Megersa N, Taddesse A, Bedassa T (2013) Determination of the levels of selected metals in seeds, flowers and fruits of medicinal plants used for tapeworm treatment in Ethiopia. Toxicol Environ Chem 95: 82-100.

23. Miller JN, Miller JC (2005) Statistics and Chemo metrics for Analytical Chemistry (5thedn), Harlow, England: Pearson.

24. Alkorta I, Hernandez-Alica J, Becerril JM, Amezaga I, Albizu I, et al. (2004) Recent findings on the phytoremediation of soils contaminated with environmentally toxic heavy metals and metalloids such as zinc, cadmium, lead and arsenic. Reviews in Environmental Science and Bio-Technology 3: 71-90.

25. Prasad MNV, Freitas $\mathrm{H}$ (2003) Metal hyper accumulation in plants - Biodiversity prospecting for phytoremediation technology. Electron J Biotechnol 6: 275-321.

26. Bigdeli M, Seilsepour M (2008) Investigation of Metals Accumulation in Some Vegetables Irrigated with Waste Water in Shahre Rey-Iran and Toxicological Implications. American-Eurasian J Agric \& Environ Sci 4: 86-92.

27. Mico C, Peris M, Sanchez J, Recatala L (2006) Heavy metal content of agricultural soils in a Mediterranean semiarid area: The Segura River Valley (Alicante, Spain). Span. J Agric Res 4: 363-372.
28. Su L, Zhang Y, Lin X (2000) Cadmium toxicity and tolerance in vascular plants Plant Nutrition and Fertilization Science 6: 106-112.

29. Cai Y, Ma LQ (2003) Metal Tolerance, Accumulation and Detoxification in Plants with Emphasis on Arsenic in Terrestrial Plants. American Chemical Society 8: 95-114.

30. WHO (2001) Codex Alimentarius Commission (FAO/WHO) Food additives and contaminants, Joint FAO/WHO. Food Standards Program ALINORM 01/12A:1 289.

31. Singh R, Singh DP, Kumar N, Bhargava SK, Barman SC (2010) Accumulation and translocation of heavy metals in soil and plants from fly ash contaminated area. J Environ Biol 31: 421-430.

32. Miclean M, Roman C, Levei E, Senila M, Abraham B, et al. (2000) Heavy metals availability for plants in a mining area from North-Western Romania. Research Institute for Analytical Instrumentation 67 Donath, Cluj-Napoca 400293.

33. Cordeiro F, Baer I, Robouch P, Emteborg H, Can SZ, et al. (2013) Setting maximum limits for trace elements in baby food in European legislation: the outcome of International Measurement Evaluation Programme $₫-33$. Food Addit Contam Part A Chem Anal Control Expo Risk Assess 30: 678-686. 